\title{
Amyloidogenicity and Clinical Phenotype Associated with Five Novel Mutations in Apolipoprotein A-I
}

\author{
Dorota Rowczenio, ${ }^{*}$ Ahmet Dogan, ${ }^{\dagger}$ \\ Jason D. Theis, ${ }^{\dagger}$ Julie A. Vrana, ${ }^{\dagger}$ \\ Helen J. Lachmann, ${ }^{*}$ Ashutosh D. Wechalekar, ${ }^{*}$ \\ Janet A. Gilbertson, ${ }^{*}$ Toby Hunt, ${ }^{*}$ \\ Simon D.J. Gibbs, ${ }^{*}$ Prayman T. Sattianayagam, ${ }^{*}$ \\ Jenny H. Pinney, ${ }^{*}$ Philip N. Hawkins, ${ }^{*}$ and \\ Julian D. Gillmore*

\begin{abstract}
From the National Amyloidosis Centre," Centre for Amyloidosis and Acute Phase Proteins, Division of Medicine, Royal Free Campus, University College London, London, England; and the Division of Anatomic Pathology, ${ }^{\dagger}$ Mayo Clinic, Rochester, Minnesota
\end{abstract}

The phenotype of hereditary apolipoprotein A-I amyloidosis is heterogeneous with some patients developing extensive visceral amyloid deposits and end-stage renal failure as young adults and others having only laryngeal and/or skin amyloid, which may be of little clinical consequence. Clinical management and prognosis of patients with systemic amyloidosis depend entirely on correct identification of the fibril protein, such that light chain amyloidosis (AL, previously referred to as "primary"), the most frequently diagnosed type, is treated with chemotherapy, which has absolutely no role in hereditary apolipoprotein A-I amyloidosis. We report five novel apolipoprotein A-I variants, four of which were amyloidogenic and one of which was incidental in a patient with systemic AL amyloidosis. Interestingly, only one of four patients with apolipoprotein A-I amyloidosis had a family history of similar disease. Laser microdissection and tandem mass spectrometrybased proteomics were used to confirm the amyloid fibril protein and, for the first time in apolipoprotein A-I amyloidosis, demonstrated that only mutated protein as opposed to wild-type apolipoprotein A-I was deposited as amyloid. The clinical spectrum and outcome of hereditary apolipoprotein A-I amyloidosis are reviewed in detail and support the need for sequencing of the apolipoprotein A-I gene among patients with apparent localized amyloidosis in whom IHC is nondiagnostic of the fibril protein, even in the absence of a family history of disease. (Am J Pathol 2011, 179:1978-1987; DOI: 10.1016/j.ajpath.2011.06.024)
Amyloidosis is a rare disorder characterized by extracellular deposition of fibrillar protein that results in a progressive disruption of structure and function of affected tissues and organs. Amyloidosis is a remarkably heterogeneous disease; it can be acquired or hereditary and systemic or localized.

The most common form of systemic amyloidosis is $\mathrm{AL}$ (light chain, previously referred to as "primary"), in which the fibrils are derived from monoclonal immunoglobulin light chains and consist of the whole or part of the variable $\left(V_{\mathrm{L}}\right)$ domain. The prognosis of systemic $\mathrm{AL}$ amyloidosis is generally worse than in other amyloid types, although there is marked heterogeneity in the extent of organ involvement and rate of disease progression. Treatment of $\mathrm{AL}$ amyloidosis is with chemotherapy for which there is no role in other amyloid types.

Hereditary systemic amyloidosis is a rare autosomal dominant condition caused by deposition of variant proteins as amyloid fibrils. The term "hereditary nonneuropathic systemic amyloidosis" (Online Mendelian Inheritance of Man no. 105200) was coined by Ostertag ${ }^{1}$ in 1932 following the discovery of two families with dominantly inherited renal amyloidosis. Mutations in the genes encoding apolipoprotein A-I (apoAI), ${ }^{2-12}$ apolipoprotein A-II (apoAll), ${ }^{13}$ fibrinogen A $\alpha$-chain, ${ }^{14-17}$ and lysozyme ${ }^{18}$ have since been identified as the cause of hereditary renal amyloidosis in different kindreds (Online Mendelian Inheritance of Man no. 105200). The clinical amyloidosis syndromes that accompany the various mutations in these different genes are diverse with respect to age at onset, mode of presentation, pattern of organ distribution, rate of progression, and prognosis. Indeed, certain apoAI variants are associated with neuropathy ${ }^{19,20}$ such that the nomenclature, which includes the term "nonneuropathic," is confusing and probably no longer appropriate.

\footnotetext{
Supported by the UK Department of Health.

Accepted for publication June 15, 2011.

The licensed patent rights to perform protein extraction from paraffinembedded tissue for the mass spectrometry-based amyloid typing test were granted by Expression Pathology, Inc.

Address reprint requests to Julian D. Gillmore, M.D., Ph.D., National Amyloidosis Centre, Centre for Amyloidosis and Acute Phase Proteins, Royal Free Campus, UCL Medical School, Rowland Hill St., London NW3 2PF, England. E-mail: j.gillmore@ucl.ac.uk.
} 
Patients with hereditary apoAl amyloidosis typically present with hypertension, proteinuria, and renal impairment ${ }^{6}$ and frequently develop extensive visceral deposits that affect the liver, spleen, and kidneys, with occasional involvement of the heart, nerves, larynx, and gastrointestinal tract. Although the condition may lead to end-stage renal disease and other organ failure, the natural history of the disease is often slow, contrasting systemic AL amyloidosis in which the median patient survival without therapy is approximately 6 to 15 months from diagnosis. ${ }^{21,22}$

Here we report five novel apoAl variants, four of which were associated with hereditary systemic amyloidosis and one of which was nonamyloidogenic, and an incidental finding discovered in a patient with systemic AL amyloidosis. The importance of correct identification of the amyloid fibril protein is highlighted, and the novel use of mass spectrometry to identify apoAl amyloidosis is reported. We review the UK National Amyloidosis Centre experience and published literature regarding the clinical spectrum and outcome of hereditary apoAl amyloidosis.

\section{Materials and Methods}

Five unrelated patients were referred to the UK National Amyloidosis Centre after discovery of amyloid deposits and underwent detailed investigations to elucidate the cause. Informed consent was obtained from all patients, and clinical care was in accordance with the Declaration of Helsinki.

\section{Patients}

A 35-year-old English man presented with hoarseness (patient 1). Vocal cord nodules were discovered at laryngoscopy and excised. A 51-year-old English woman presented with a soft tissue mass growing on her palate (patient 2). A 29-year-old Polish woman presented with edema (patient 3). A 77-year-old English woman presented with hypertension and was noted to have proteinuria and renal impairment (patient 4). A 56-yearold English man presented with proteinuria and progressive renal impairment (patient 5).

\section{Histology and IHC}

Biopsy specimens of vocal cord and testicles from patient 1 , palatal mass from patient 2 , rectum from patient 3 , and kidney from patients 4 and 5 were stained at the UK National Amyloidosis Centre. Sections, 6- $\mu \mathrm{m}$ thick, were stained for amyloid deposits with Congo red and viewed under crossed polarized light. ${ }^{23}$ Immunohistochemistry $(\mathrm{IHC})$ staining of the amyloid deposits was performed using monospecific antibodies reactive with serum amyloid A protein, lysozyme, apoAl, fibrinogen A $\alpha$-chain, transthyretin, and $\kappa$ and $\lambda$ immunoglobulin light chains, as previously described. ${ }^{24}$ Specificity of staining was confirmed by prior absorption of the antiserum with pure antigen in each case, and positive and negative controls were included in each run.

\section{Direct DNA Sequencing}

Genomic DNA from all five patients was extracted from whole blood treated with EDTA. ${ }^{25}$ Exons 3 (c.5352 to c.5711) and 4 (c.6116 to 6859) of the APOAl gene (National Center for Biotechnology Information accession no. NG_012021) were amplified by PCR performed with ReadyTo-Go tubes (Amersham Pharmacia Biotech, Piscataway, NJ). PCR amplification of exons 3 and 4 was performed with the following oligonucleotides: exon 3 forward 5'-GGCAGAGGCAGCAGGTTTCTCAC-3' (c.5352-5374) and reverse 5'-CCAGACTGGCCGAGTCCTCACCTA-3' (c.56885711) and exon 4 forward 5'-CACTGCACCTCCGCGGACA-3' (c.6116-6134) and reverse 5'-CTTCCCGGTGCTCAGAATAAACGTT-3' (c.6835-6859). The total volume of PCR reaction was $25 \mu \mathrm{L}$, and it consisted of the following: $2 \mu \mathrm{L}$ of DNA (at a concentration of $100 \mathrm{ng} / \mu \mathrm{L}$ ), $1 \mu \mathrm{L}$ of each primer (at a concentration of $10 \mu \mathrm{mol} / \mathrm{L}$ ), and $21 \mu \mathrm{L}$ of water. PCR cycling conditions were as followed: initial denaturation at $96^{\circ} \mathrm{C}$ for 5 minutes; five cycles of $96^{\circ} \mathrm{C}$ for 30 seconds and $72^{\circ} \mathrm{C}$ for 30 seconds; 35 cycles at $96^{\circ} \mathrm{C}$ for 30 seconds, $72^{\circ} \mathrm{C}$ for 30 seconds, and $72^{\circ} \mathrm{C}$ for 1 minute; and final elongation step at $72^{\circ} \mathrm{C}$ for 7 minutes. Negative and positive controls were included.

The PCR products were purified with a QIAquick PCR purification kit (Oiagen, Velno, the Netherlands) according to the manufacturer's protocol and sequenced with the ABI BigDye Terminator v 3.1 Ready Reaction Cycle Sequencing kit (Applied Biosystems, Foster City, CA). The primers 5'GATCTCAGCCCACAGCTGGCC-3' (c.5417-5437) and 5'-AGGGCTCACCCCTGATAGGCTG-3' (c.6144-6166) were used for sequencing of exons 3 and 4 , respectively. $A P O A /$ gene sequences were analyzed on the $A B|3130 x|$ Genetic Analyzer, using Sequencing Analysis Software, version 5.4 (Applied Biosystems, Carlsbad, CA).

\section{Laser Microdissection and Tandem Mass Spectrometry-Based Proteomics}

The proteome of amyloid deposits was analyzed by combining microdissection and mass spectrometry-based proteomics. Sections (10- $\mu \mathrm{m}$ thick) of formalin-fixed, paraffin-embedded tissues were placed on DIRECTOR slides (Expression Pathology, Rockville, MD). Sections were air dried and then melted, deparaffinized, and stained in hematoxylin followed by Congo red.

Congo red-stained sections were examined for the presence of amyloid deposits under fluorescence (B/G/R filter cube; Leica, Wetzler, Germany). Positive areas were microdissected into $0.5-\mathrm{mL}$ microcentrifuge tube caps containing $10 \mathrm{mmol}$ TRIS/1 mmol EDTA/0.002\% Zwittergent 3-16 (Calbiochem, San Diego, CA) using a Leica DM6000B Microdissection System (Leica). For each case, two to four different microdissections were collected, and each microdissection contained 50,000 to $60,000 \mu \mathrm{m}^{2}$ of the tissue section. Collected tissues were heated at $98^{\circ} \mathrm{C}$ for 90 minutes with occasional vortexing. After 60 minutes of sonication in a waterbath, samples were digested overnight at $37^{\circ} \mathrm{C}$ with $1 \mu \mathrm{g}$ of trypsin 
(Promega, Madison, WI). The trypsin-generated digests were reduced with dithiothreitol and separated by nanoflow liquid chromatography-electrospray tandem mass spectrometry using a ThermoFinnigan LTQ Orbitrap Hybrid Mass Spectrometer (Thermo Electron, Bremen, Germany) coupled to an Eksigent nanoLC-2D HPLC system (Eksigent, Dublin, CA). A 0.25- $\mu \mathrm{L}$ trap (Optimize Technologies, Oregon City, OR) packed with Michrom Magic C-8 was plumbed into a 10-port valve. A $75 \mu \mathrm{m} \times 15 \mathrm{~cm}$ C-18 column was used for the separation using an organic gradient from $6 \%$ to $86 \%$ in 55 minutes at 400 $\mathrm{nL} / \mathrm{min}$. The Thermo-Fisher Scientific (Waltham, MA) MS/MS raw data files were searched using three different algorithms (Mascot, Sequest, and X!Tandem) and the results assigned peptide and protein probability scores. The results were then combined and displayed using Scaffold (Proteome Software, Portland, OR). All searches were conducted with variable modifications and restricted to full trypsin-generated peptides, allowing for two missed cleavages. Peptide mass search tolerances were set to $10 \mathrm{ppm}$ and fragment mass tolerance to 1.00 Da. The search algorithms used to identify peptides interrogate the human SwissProt database, which does not contain the mutated sequences identified in this study. To show that the peptides containing the mutation were part of amyloid deposits, these sequences were added to the human SwissProt database using an in-house script, and a second-round data analysis was performed. Peptide identifications below the $90 \%$ confidence level were not considered in our analysis.

\section{Radiolabeled SAP Scintigraphy}

All five patients underwent whole body anterior and posterior scintigraphic imaging 24 hours after administration of ${ }^{123}$-labeled serum amyloid $\mathrm{P}$ component (SAP) using a GE Infinia Hawkeye (GE Healthcare, Chalfont St Giles, UK) gamma camera, as previously described. ${ }^{26}$ The labeled SAP study results were interpreted by a panel of physicians with experience of more than 10,000 SAP scans.

\section{Results}

\section{Clinical Findings}

Patient 1 presented with a hoarse voice and no other significant history. He underwent direct laryngoscopy and excision of multiple nodules on the vocal cords and aryepiglottic folds, which were discovered to be amyloid on histologic analysis. On direct questioning there was no history of hemoptysis, dyspnea, rashes, petechiae, weight loss, anorexia, or edema. There was no history of paraesthesia or postural dizziness. The only medical history was of hypogonadism and azoospermia for which he had undergone a testicular biopsy 8 to 10 years previously. He did not take regular medication, and there was no family history of similar illness, cardiac disease, or renal disease. Clinical examination was unremarkable. Baseline investigations showed normal blood cell count, clotting profile, renal, and liver function. There was no evidence of a plasma cell dyscrasia by sensitive nephelometric serum free light chain assay, ${ }^{27}$ conventional electrophoresis and immunofixation of serum or urine, or bone marrow examination. There was no proteinuria, and ECG and echocardiography did not reveal evidence of cardiac amyloid infiltration.

Patient 2 presented with a 4-year history of a gradually enlarging mass on the palate within an area of scarring from a childhood injury. There had been no bleeding or pain associated with the lump, and the patient remained otherwise well. She experienced an occasional dry mouth and dry eyes and very rare tingling in her fingertips, with no other features to suggest a peripheral neuropathy or carpal tunnel syndrome. There was no history of weight loss or autonomic symptoms. There was no family history of amyloidosis, renal disease, or cardiac disease. Clinical examination was unremarkable. She had a medical history that included celiac disease, dermatitis herpetiformis, and multinodular goiter for which she had undergone a partial thyroidectomy at the age of 29 years. Shortly before her presentation with the lump in the palate, she had developed a recurrent clinically overt goiter. There was no evidence of a plasma cell dyscrasia by serum free light chain assay, conventional electrophoresis and immunofixation of serum or urine, or bone marrow examination. There was no proteinuria, and ECG, echocardiogram, and $\mathrm{N}$-terminal pro-B-type natriuretic peptide were not suggestive of cardiac amyloid infiltration.

Patient 3 presented with edema and was discovered to have subnephrotic range proteinuria $(1.68 \mathrm{~g} / 24 \mathrm{~h})$ and stage 3 chronic kidney disease (CKD). A kidney biopsy was performed in 2008 and revealed amyloidosis, thought on initial IHC in her local hospital to be AA type. The results of investigations to identify an underlying inflammatory condition were all negative. Treatment with colchicine was commenced empirically, and she was referred to the UK National Amyloidosis Centre. There was no history of chronic inflammatory disease in her or her family and no family history of kidney disease. There was no history to suggest peripheral or autonomic neuropathy and no dyspnea. Baseline investigations revealed normal blood cell count, clotting profile, and liver function. There was no evidence of a plasma cell dyscrasia. An echocardiogram demonstrated a 12-mm interventricular wall thickness but normal diastolic dysfunction and good left ventricular systolic function, but there was mild thickening of her heart valves; overall, there was no definite evidence of cardiac amyloidosis, but it could not be completely excluded. There was insufficient tissue remaining in her renal biopsy specimen to definitively confirm the amyloid type, and there was doubt about the diagnosis of AA amyloidosis; therefore, a rectal biopsy was requested.

Patient 4 presented with hypertension and was discovered to be nephrotic (7.9 g/24 h; serum albumin, $24 \mathrm{~g} / \mathrm{L}$ ) with CKD stage 3 on a background of type 2 diabetes mellitus and ischemic heart disease. A renal biopsy specimen revealed amyloid deposits in the glomeruli and interstitium. At presentation, she was experiencing paraesthesia in the feet and minimal dyspnea on exertion. There was no evidence of a plasma cell dyscrasia. Cardiac investigations did not suggest amyloid cardiomyop- 

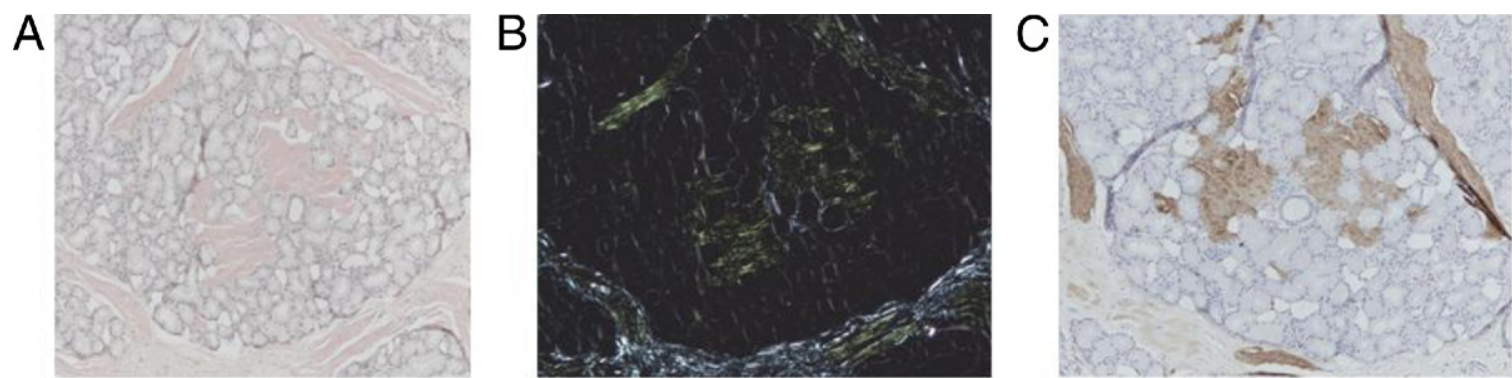

Figure 1. Palate biopsy specimen from a patient with apoAI amyloidosis. Staining with Congo red viewed under bright field light (A) showed amorphous eosinophilic deposits, which showed apple green birefringence when viewed under crossed polarized light (B) diagnostic of amyloid. The amyloid deposits stained with an antibody against apoAI (C), and staining was completely abolished by prior incubation of the antiserum with pure apoAI, thus confirming apoAI as the amyloid fibril protein.

athy. The patient's sister was subsequently discovered to have amyloid deposits on a renal biopsy specimen, undertaken for proteinuria.

Patient 5 presented with edema and was discovered to have proteinuria, advanced CKD, and mildly obstructive derangement of liver function tests. A renal biopsy specimen revealed amyloid deposits. There was mild breathlessness on exertion but no clinical evidence of peripheral or autonomic neuropathy. Nephelometric serum free light chain assay revealed a marked $\kappa$ excess ( $\kappa, 393 \mathrm{mg} / \mathrm{L} ; \lambda, 30 \mathrm{mg} / \mathrm{L}$ ). There was no paraprotein by serum or urine immunoelectrophoresis, and bone marrow examination revealed less than $5 \%$ clonal plasma cells. Cardiac investigations did not show any evidence of cardiac involvement by amyloid. The patient received 15 days of high-dose dexamethasone for presumed AL amyloidosis, which substantially suppressed the $\kappa$ serum free light chain concentration. Despite this, however, there was a progressive decline in renal function and the patient commenced hemodialysis.

\section{Histology and IHC}

Extensive amyloid deposits were identified in the vocal cord and testes of patient 1 , the palate of patient 2, the rectum of patient 3 , and the kidneys of patients 4 and 5 by their pathognomonic green birefringence when
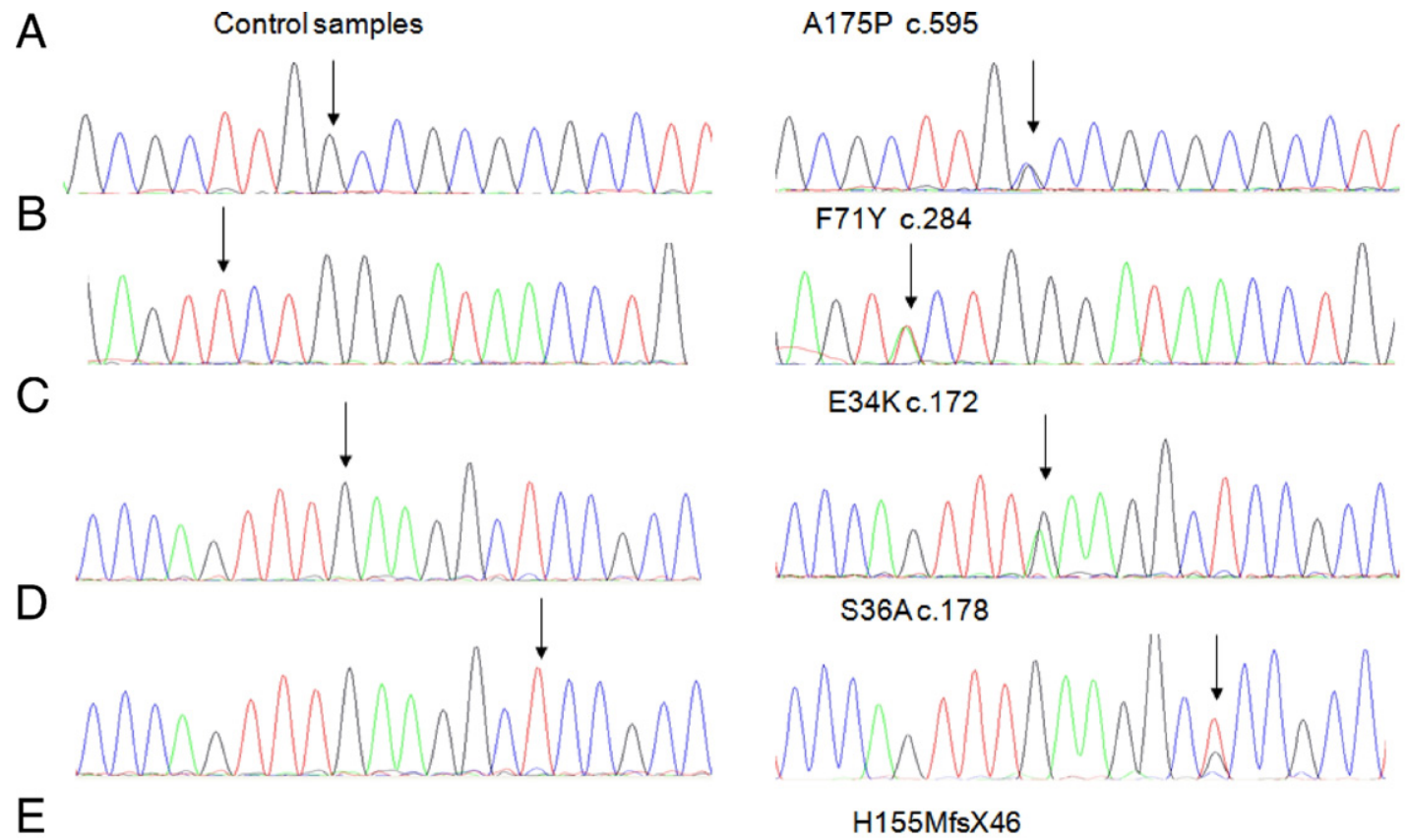

F71Y c.284
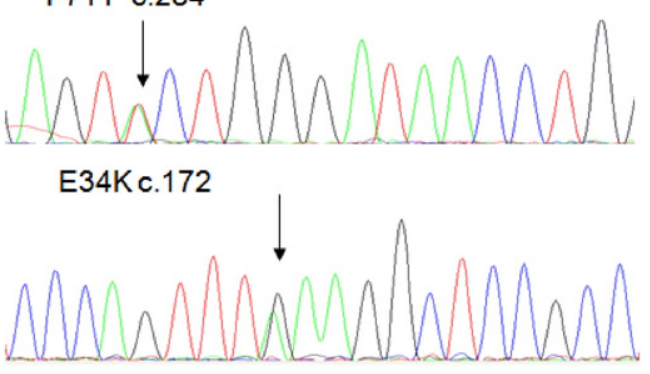

S36Ac. 178

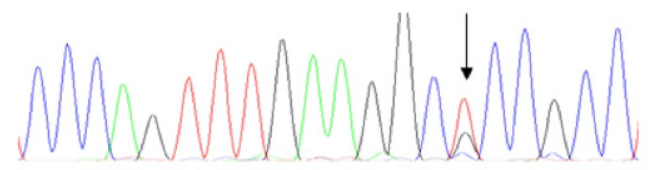

H155MfsX46
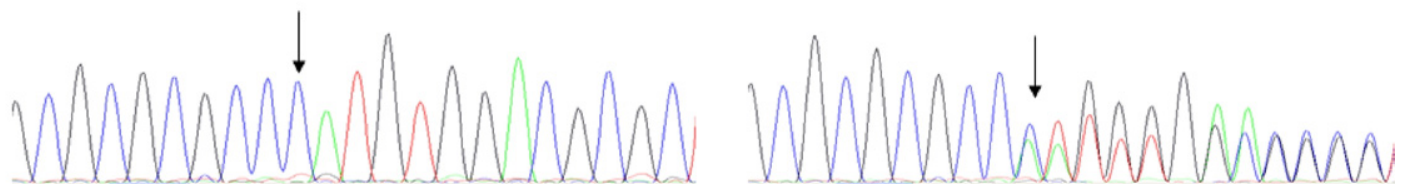

Figure 2. Partial DNA sequences of exons 3 and 4 of the $A P O A I$ gene. Right column shows five novel mutations indicated by arrows; four single nucleotide substitutions: A175P (A), F71Y (B), E34K (C), S36A (D), and a frameshift mutation H155MfsX46 (E). Left column shows the corresponding wild-type sequences. 
A

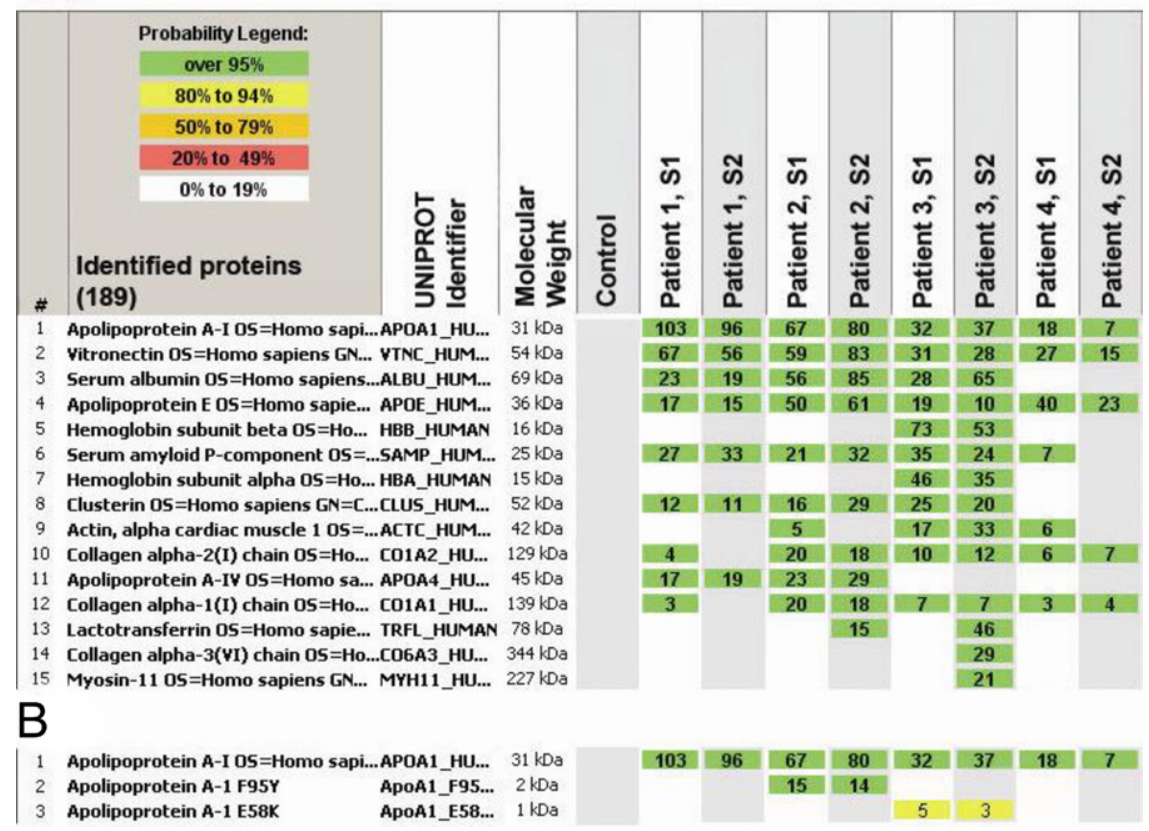

Figure 3. Results of mass spectrometry-based proteomic analysis of amyloid deposits $(\mathbf{A})$. The 15 most abundant proteins identified among four patients are listed. At least two different samples (S1 and S2) were run for each patient. The columns show the protein name, the UnitProt identifier (protein accession code in the UniProt database, http://www.uniprot.org), the molecular weight of the protein, the results of the blank control sample, and two samples from each of the four patients. The numbers indicate number of total peptide spectra identified for each protein. ApoAI is the most abundant protein in this sample set, confirming apoAI as the amyloid fibril protein. Identification of mutated protein in amyloid deposits by mass spectrometry-based proteomics (B). After addition of the mutated sequences to the human SwissProt database using an in-house script and a secondround data analysis, the presence of mutated protein (a tryptic peptide carrying the altered amino acid sequence) within the amyloid deposits of patients 2 and 3 was demonstrated. The nomenclature for the location of the mutated amino acid includes the 24 amino acid signal peptide; thus, F95Y and E58K in the figure correspond to the $\mathrm{F} 71 \mathrm{Y}$ and $\mathrm{E} 34 \mathrm{~K}$ protein variants, respectively.

stained with Congo red and viewed under crossed polarized light (Figure 1A-B). The amyloid from patients 1 through 4 stained specifically with antibodies to apoAl (Figure 1C), and staining was completely abolished by prior absorption of the antiserum with an excess of pure human apoAl. There was no other staining with antibodies to $\kappa$ light chains and no staining with antibodies against other known amyloid fibril proteins, including lysozyme, transthyretin, serum amyloid A protein, or $\lambda$ light chains. The amyloid from patient 5 stained with antibodies against both $\kappa$ light chains and apoAl such that IHC results were inconclusive.

\section{APOAI Gene Mutations}

Genetic analysis of exons 3 and 4 of the APOAl gene revealed five novel mutations (Figure 2). Four were single nucleotide substitutions, c.595G $>$ C, c.284T $>A$, c. $172 \mathrm{G}>\mathrm{A}$, and c. $178 \mathrm{~T}>\mathrm{G}$, resulting in amino acid change: alanine to proline at position 175, A175P in patient 1; phenylalanine to tyrosine at position 71, F71Y in patient 2; glutamic acid to lysine at position 34, E34K in patient 3; and serine to alanine at position 36, S36A in patient 5, respectively. The other novel variant p. His155MetfsX46, discovered in patient 4, resulted from a frameshift mutation caused by a deletion of cytosine at position c.535. The new reading frame created by this single nucleotide deletion results in premature termination, and consequently the mutated protein was 44 nucleotides shorter than wild-type apoAl. The remainder of the APOAl gene in all five patients was identical to the published sequence. ${ }^{28}$

\section{Amyloid Typing by Laser Microdissection and Tandem Mass Spectrometry-Based Proteomics}

Laser microdissection and tandem mass spectrometry showed that, in patients 1 through 4 , apoAl was one of

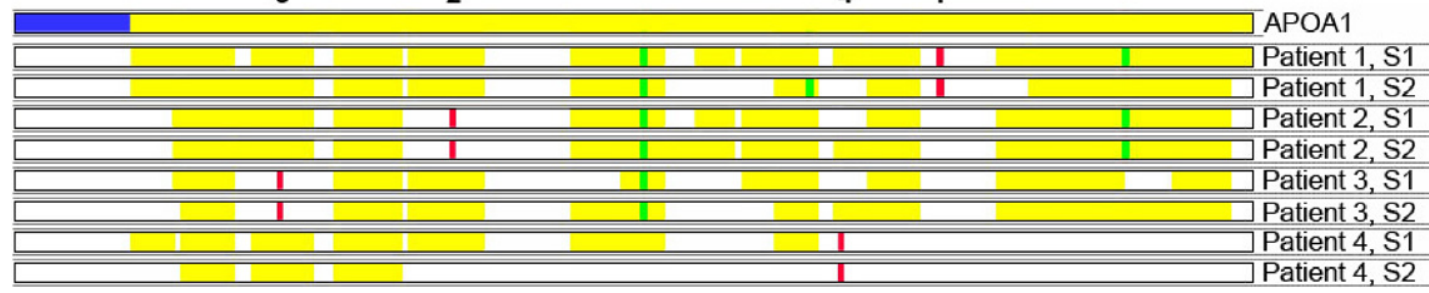

Figure 4. ApoAI protein coverage in apoAI amyloidosis. The top line represents the native apoAI protein (signal peptide in blue and secreted protein in yellow) The numbers above the top line indicate the individual patient's number throughout this article. Two samples (S1 and S2) from four patients are shown. The location of the amino acid residues affected by the mutations in each patient are represented by red bars and oxidized residues are represented by green bars. Most of the apoAI protein is deposited in patients 1,2 , and 3, but the tryptic peptides carrying the variant amino acid sequence are notably absent. In patient 4 , where the mutation identified is predicted to cause a frameshift, only the N-terminal part of the protein before the mutation is present. The absence of the peptide carrying the mutated amino residue in each of these four patients indicates that the amyloid fibrils were composed solely of mutated protein and not wild-type apoAI. As discussed in the text, mutated peptides are not detected by the algorithms that only interrogate the data for wild-type sequences. If wild-type apoAI encoded by the normal allele had been incorporated into the amyloid deposits, these peptides would have been detected. 
the most abundant proteins present in the amyloid deposits (Figure $3 \mathrm{~A}$ ). In contrast, there were no apoAl peptides present in the amyloid deposits of patient 5 , which were composed of $\kappa$ light chains. In addition to apoAl, other identified proteins included serum proteins, such as vitronectin and albumin, along with proteins that are known to be associated with all types of amyloidosis, such as apolipoprotein $\mathrm{E}$ and serum amyloid $\mathrm{P}$ component.

\section{Identification of Mutated Protein in Amyloid Deposits by Tandem Mass Spectrometry-Based Proteomics}

To show the presence of mutated proteins in the amyloid deposits, we searched the mass spectrometry raw data files using the human SwissProt database supplemented with the $A P O A /$ gene variants identified in this study. The mutated protein (a tryptic peptide carrying the altered amino acid sequence) was present in the amyloid deposits of patients 2 and 3 (Figure 3B). Detailed examination of the apoAl protein coverage showed that certain tryptic peptides, which would have been present had protein encoded by the normal allele been incorporated into amyloid deposits, were absent, indicating that only the protein encoded by the abnormal allele was amyloidogenic (Figure 4). Interestingly, the mutation in patient 1 affected an area of the protein that cannot be detected by the mass spectrometry-based proteomics technology used in the study due to the presence of numerous trypsin cutting sites in this area (Figure 4). In patient 4, the frameshift mutation in APOAl generates a novel $\mathrm{C}$ terminus amino acid sequence, which, theoretically, could be detected by mass spectrometry-based proteomics. Although this novel sequence was included in our supplemented database, we did not identify peptides representing the novel sequence, suggesting that this part of the protein was unstable and was most likely cleaved, generating a truncated apoAl protein that was deposited as amyloid.

\section{SAP Scintigraphy}

SAP scintigraphy did not show any visceral amyloid deposits in patient 1 and showed only renal amyloid deposits in patients 4 and 5. Subclinical hepatic amyloid deposits were detected in patient 2. A large amyloid load affecting the spleen and liver with an obscured kidney signal was identified in patient 3 . It should be noted that amyloid deposits in the skin, vocal cord, heart, nerves, and testes do not show up by this technique.

\section{Discussion}

Determining the fibril protein remains a challenge in many patients with amyloidosis. Indeed, AL amyloidosis, the most commonly diagnosed systemic form of amyloid, is not infrequently a diagnosis of exclusion, which is complicated by the fact that there is considerable overlap between the clinical features of the different amyloid types. Furthermore, it is important to recognize that the presence of a plasma cell dyscrasia, which occurs in approximately $3 \%$ of the population older than 50 years and approximately $5 \%$ of those older than 70 years, ${ }^{29}$ in a patient with amyloidosis does not prove AL type and may be incidental to their amyloidosis. ${ }^{30}$ The deposits in approximately $20 \%$ of patients with $\mathrm{AL}$ amyloidosis fail to stain with antibodies against $\kappa$ and $\lambda$ immunoglobulin light chains, presumably reflecting the fact that the fibrils consist of misfolded, variable light chain domains within which certain epitopes may be masked. ${ }^{31-33}$ Similarly, to confirm the amyloidogenicity of a novel mutation, even within a known amyloid fibril protein gene, one is required to demonstrate the protein composition of the amyloid fibrils. Until recently, this could only be achieved by IHC or direct protein sequencing. The latter is technically challenging and requires a substantial quantity of fresh tissue, which often cannot be obtained during life. Classification of amyloidosis by mass spectrometry-based proteomic analysis therefore represents a significant advance in amyloid diagnostics, enabling the fibril protein to be reliably identified from small quantities of formalinfixed tissue. ${ }^{33}$

The demonstration, by $\mathrm{IHC}$ and/or mass spectrometry, that the amyloid fibrils in four patients were composed of apoAl in conjunction with a typical phenotype of laryngeal involvement in patient 1 , liver amyloidosis in patient 2 , liver and renal manifestations in patient 3 , and renal amyloidosis in patient 4 indicates that these novel APOAl mutations were the cause of their amyloidosis. The IHC was supported by mass spectrometry-based proteomics, which confirmed, for the first time in apoAl amyloidosis, that the amyloid fibrils were composed uniquely of variant protein. Interestingly, only one of these four patients had a family history of amyloidosis. The absence of a family history is apparently unusual in apoAl amyloidosis and might suggest a de novo mutation; however, variable penetrance is well recognized in other types of hereditary systemic amyloidosis. ${ }^{34}$ We have not been able to obtain DNA from the parents of the three relevant patients to investigate this in more detail. Patient 5 presented a diagnostic challenge. In the presence of a $\kappa$ light chain-secreting clonal dyscrasia and a novel APOA1 mutation, the $\mathrm{IHC}$ was nondiagnostic of the amyloid fibril protein. Only laser microdissection of amyloid fibrils from fixed tissue and mass spectrometry enabled definitive confirmation of monoclonal $\kappa$ light chain-derived $(\mathrm{AL})$ rather than apoAl amyloidosis in this patient. ${ }^{33}$ The mass spectrometry findings were later corroborated by SAP scintigraphic evidence of amyloid regression in response to successful suppression of $\kappa$ light chain production with steroids, thereby excluding apoAl amyloidosis.

ApoAl (Mendelian Inheritance of Man no. 107680) is synthesized in the liver and small intestine and is encoded by a gene located on chromosome 11q23-q24. It is the major protein component of high-density lipoprotein in plasma, and it promotes efflux of cholesterol from cells. The APOAl gene sequence is composed of 8870 nucleotides (National Center for Biotechnology Information accession no. NG_012021) encoding a 267 amino acid primary transcript containing an 18-amino acid prepeptide and 6-amino acid propeptide connected to the 
Table 1. Summary of $A P O A I$ Mutations Associated with Amyloidosis, Clinical Phenotype, and Outcome

\begin{tabular}{|c|c|c|c|}
\hline APOA1 variant & Ethnicity & Clinical presentation & $\begin{array}{l}\text { Age at presentation, } \\
\text { years/family history }\end{array}$ \\
\hline Gly26Arg $2,19,36,37$ & British Scandinavian & $\begin{array}{l}\text { HTN, renal impairment, macroscopic } \\
\text { hematuria }\end{array}$ & $20-46 / Y$ \\
\hline Glu34Lys (current study) & Polish & $\begin{array}{l}\text { Renal impairment, subnephrotic } \\
\text { proteinuria }\end{array}$ & 29/Unknown \\
\hline $\operatorname{Trp50Arg}^{4}$ & Jewish (Ashkenazi) & $\begin{array}{l}\text { Macroscopic hematuria, proteinuria, } \\
\text { renal impairment }\end{array}$ & $34 / Y$ \\
\hline Leu60Arg $^{3}$ & British & $\begin{array}{l}\text { HTN, renal impairment, macroscopic } \\
\text { hematuria }\end{array}$ & $24 / Y$ \\
\hline Leu64Pro $^{11}$ & Italian & Proteinuria, renal impairment & 56-58/Unknown \\
\hline Leu60_Phe71delins 60Val_61Thr ${ }^{5,38}$ & Spanish & $\begin{array}{l}\text { Hepatomegaly and abnormal LFT } \\
\text { results }\end{array}$ & $35-45 / Y$ \\
\hline Glu70_Trp72del ${ }^{39}$ & British & HTN, renal impairment & $18-21 / Y$ \\
\hline Asn74Lysfs ${ }^{40}$ & German & $\begin{array}{l}\text { Renal impairment, tumor of the right } \\
\text { ovary }\end{array}$ & 48/Unknown \\
\hline $\begin{array}{l}\text { Phe71Tyr (current study) } \\
\text { Leu75Pro }{ }^{12,40-42}\end{array}$ & $\begin{array}{l}\text { British } \\
\text { Italian/German/Other }\end{array}$ & $\begin{array}{l}\text { Palatal mass } \\
\text { Hepatomegaly, renal impairment }\end{array}$ & $\begin{array}{l}\text { 51/Unknown } \\
42-70 / Y\end{array}$ \\
\hline Leu90Pro $^{8}$ & French/American & $\begin{array}{l}\text { Skin lesions, cardiomyopathy (later), } \\
\text { dysphonia }\end{array}$ & $37-51 / Y$ \\
\hline Lys107del ${ }^{43}$ & Scandinavian & Angina & 45/Unknown \\
\hline Ala154fs $X 47^{40}$ & German & Renal impairment & 58/Unknown \\
\hline Leu170Pro ${ }^{40}$ & German & Laryngeal amyloid deposits & 52/Unknown \\
\hline His155MetfsX46 (current study) & British & $\begin{array}{l}\text { HTN, nephrotic syndrome, renal } \\
\text { impairment }\end{array}$ & 77/Unknown \\
\hline Arg173Pro $^{7}$ & American/British & $\begin{array}{l}\text { Skin lesions, dysphonia, } \\
\text { cardiomyopathy (later) }\end{array}$ & $20-45 / Y$ \\
\hline Leu174Ser $^{9,20}$ & Italian/Dutch & $\begin{array}{l}\text { Infertility, rash, cardiomyopathy, } \\
\text { dysphonia }\end{array}$ & $42-45 / Y$ \\
\hline Ala175Pro (current study) & British & Dysphonia & 38/Unknown \\
\hline Leu178His $^{10,20}$ & French & Dysphonia, cardiomyopathy & $\begin{array}{l}34 / Y \\
\text { (table continues) }\end{array}$ \\
\hline
\end{tabular}

A, adrenal glands; CABG, coronary artery bypass graft; CAD, coronary artery disease; ESRD, end-stage renal disease; GI, gastrointestinal; HTN, hypertension; L, liver; LFT, liver function test; OLT, orthotopic liver transplantation; PM, post-mortem; S, spleen; TIN, tubulointerstitial nephritis.

amino terminus of the 243 amino acid mature apoAl. ${ }^{35}$ Although the precise mechanism for the amyloidogenicity of variant apoAl remains unclear, it has been shown that mutated apoAl undergoes proteolytic cleavage releasing the amyloidogenic N-terminal fragment from the fulllength protein. $., 7,9$

There are now 19 mutations in the APOAl gene known to be association with hereditary systemic apoAl amyloidosis, including the four novel amyloidogenic variants described here (Table 1). The phenotype of apoAl amyloidosis may be fairly aggressive and present in teenagers with CKD, hepatomegaly, cardiomyopathy, and sometimes neuropathy ${ }^{19,44}$ or may be extremely indolent and clinically insignificant. Interestingly, most C-terminal variants seem to be associated with hoarseness due to laryngeal amyloid deposits (Table 1), ${ }^{7,9,10,20,40}$ although there is even substantial heterogeneity in the age at onset and clinical manifestations between patients with identical mutations. G26R, which is the most frequently reported amyloidogenic apoAl variant among Northern Europeans, is associated with amyloid de- 
Table 1. Continued

\begin{tabular}{|c|c|c|c|}
\hline $\begin{array}{l}\text { Organ involvement by } \\
\text { amyloid }\end{array}$ & $\begin{array}{l}\text { SAP scintigraphic } \\
\text { findings }\end{array}$ & $\begin{array}{l}\text { Organs not involved to } \\
\text { date }\end{array}$ & Clinical outcome \\
\hline $\begin{array}{l}\text { Kidneys, liver, peripheral } \\
\text { nerves, Gl tract } \\
\text { (peptic ulcers) }\end{array}$ & $\begin{array}{l}\text { Large load: liver, spleen, } \\
\text { kidneys }\end{array}$ & Heart & $\begin{array}{l}\text { Slowly progressive CKD, dialysis } 11-20 \text { years after } \\
\text { presentation. Excellent outcome with } \\
\text { transplantation of kidney with or without liver. } \\
\text { Death at } 47 \text { years of age with renal failure } \\
\text { reported. Death after } 1-18 \text { years reported }\end{array}$ \\
\hline Kidneys, liver & $\begin{array}{l}\text { Large load: spleen and } \\
\text { liver, small kidney }\end{array}$ & Heart, nerves & Slowly progressive renal failure \\
\hline Kidneys, liver, Gl tract & $\begin{array}{l}\text { Large load: liver, spleen, } \\
\text { kidneys }\end{array}$ & Heart, nerves & $\begin{array}{l}\text { Progressive renal failure, no reports of successful } \\
\text { renal transplantation. Death at the age of } 45 \\
\text { years (after } 10 \text { years), massive liver and renal } \\
\text { amyloidosis }\end{array}$ \\
\hline $\begin{array}{l}\text { Kidneys, liver, testes, } \\
\text { heart }\end{array}$ & $\begin{array}{l}\text { Large or small load: } \\
\quad \text { liver, spleen, kidneys }\end{array}$ & Nerves & $\begin{array}{l}\text { Good with single organ (kidney, heart) } \\
\text { transplantation. Regression after liver } \\
\text { transplantation. Death between } 35 \text { and } 65 \text { years } \\
\text { of age from "amyloidosis" }\end{array}$ \\
\hline Kidneys, liver & $\begin{array}{l}\text { Large load: liver, spleen, } \\
\text { kidneys }\end{array}$ & Heart, nerves & $\begin{array}{l}\text { Progressive renal failure, death at } 69 \text { years of age } \\
\text { with renal failure, good outcome with renal } \\
\text { transplantation }\end{array}$ \\
\hline Liver & Large load: liver, spleen & Heart, kidneys, nerves & $\begin{array}{l}\text { Progressively abnormal LFT results (usually slow), } \\
\text { liver failure, no reports of successful OLT. Death } \\
\text { at } 48-66 \text { years of age, after } 1-20 \text { years }\end{array}$ \\
\hline Kidneys, liver, choroid & $\begin{array}{l}\text { Large load: liver, spleen, } \\
\text { kidneys }\end{array}$ & Heart, nerves & $\begin{array}{l}\text { ESRD } 5 \text { years after presentation. Death at } 32 \text { years } \\
\text { of age and middle-age reported. Excellent } \\
\text { outcome with renal transplantation. (No clinical } \\
\text { sequelae of liver and spleen involvement.) }\end{array}$ \\
\hline $\begin{array}{l}\text { Kidneys, uterus, ovaries, } \\
\text { pelvic lymph nodes, } \\
\text { Gl tract }\end{array}$ & Never performed & Not listed & Not mentioned \\
\hline Liver, palate & Moderate load: liver & Heart, nerves, kidneys & Good outcome up to 52 years of age \\
\hline Kidneys, liver, testes & Never performed & Heart, nerves, spleen & $\begin{array}{l}\text { Gradually progressive liver amyloidosis, CKD, and } \\
\text { TIN with death at } 67-90 \text { years of age, good } \\
\text { outcome }\end{array}$ \\
\hline Skin, heart, larynx & $\begin{array}{l}\text { Never performed L, S, A } \\
\text { at autopsy }\end{array}$ & Nerves, kidneys & $\begin{array}{l}\text { Progressive cardiac failure and death at } 41-70 \\
\text { years of age, no reports of successful heart } \\
\text { transplantation }\end{array}$ \\
\hline $\begin{array}{l}\text { Aortic intimal amyloid; } \\
\text { not known (PM study) }\end{array}$ & Never performed & Nerves, kidneys & $\begin{array}{l}\text { Premature CAD, required CABG, and developed } \\
\text { abdominal aortic aneurysm. Died at } 68 \text { years of } \\
\text { age }\end{array}$ \\
\hline Kidneys & Never performed & Not listed & Not mentioned \\
\hline Larynx & Never performed & Not listed & Not mentioned \\
\hline Kidneys & Small load: kidneys & Heart, liver & CKD, short follow-up \\
\hline $\begin{array}{l}\text { Kidneys, skin, heart, } \\
\text { larynx }\end{array}$ & $\begin{array}{l}\text { Small load with } \\
\text { equivocal kidneys }\end{array}$ & Nerves, spleen & $\begin{array}{l}\text { Progression of cardiomyopathy and renal failure, } \\
\text { death at 52-63 years of age, good outcome with } \\
\text { cardiac and renal transplantation }\end{array}$ \\
\hline $\begin{array}{l}\text { Skin, testes, heart, } \\
\text { larynx, nerves }\end{array}$ & $\begin{array}{l}\text { Small load: no visceral } \\
\text { amyloid deposits }\end{array}$ & Nerves, liver, spleen & $\begin{array}{l}\text { Progressive cardiomyopathy, death at } 50-52 \text { years } \\
\text { of age, good outcome after cardiac } \\
\text { transplantation }\end{array}$ \\
\hline Larynx, testes & $\begin{array}{l}\text { Small load: no visceral } \\
\text { amyloid deposits }\end{array}$ & $\begin{array}{l}\text { Heart, nerves, liver, } \\
\text { spleen, kidneys }\end{array}$ & Good outcome up to 43 years of age \\
\hline $\begin{array}{l}\text { Larynx, skin, heart, } \\
\text { nerves }\end{array}$ & Never performed & Liver, spleen & $\begin{array}{l}\text { Progressive cardiomyopathy, death at } 39 \text { years of } \\
\text { age }\end{array}$ \\
\hline
\end{tabular}

position in the peripheral nerves, as well as the kidneys, liver, and gastrointestinal tract. ${ }^{36,45}$ Patient 4 in this series presented with symptoms of possible neuropathy and is awaiting confirmatory tests. Two other apoAl variants, $\mathrm{L} 174 \mathrm{~S}$ and $\mathrm{L} 178 \mathrm{H}$, are reportedly associated with varying degrees of neuropathy. ${ }^{20}$ Here we report the sixth apoAl variant to be associated with laryngeal amyloidosis, Ala175Pro. The nucleotide change in each of the previous kindreds occurred close to the carboxyl terminus (Leu170Pro, ${ }^{40}$ Arg173Pro, ${ }^{7}$ Leu174Ser, $^{9,20}$ Leu178His $^{10}$ ) apart from that in an Italian family with laryngeal, cardiac, and skin amyloidosis who carried the Leu90Pro apoAl variant. ${ }^{8}$ His 155Metfs X46 is the third reported amyloidogenic frameshift mutation in the APOAl gene. The other two, Asn74fs and Ala154fs, were recently described by Rocken and coworkers. ${ }^{40}$ Interestingly, all three patients with frameshift mutations presented with renal manifestations.

In conclusion, we report here five novel apoAl variants, four of which cause hereditary systemic amyloidosis. Mass spectrometry-based proteomics identified apoAl 
as the main constituent of amyloid deposits in all four patients with pathogeneic $A P O A$ / mutations and was successful in identifying the amyloid fibril protein as monoclonal light chain $(A L)$ rather than apoAl in one patient who had both a clonal dyscrasia and a novel APOAl mutation whose $\mathrm{IHC}$ was nondiagnostic of the fibril protein. Minimal formalin-fixed amyloidotic tissue is required for the procedure, making this an invaluable new diagnostic tool for amyloid typing. The substantial phenotypic heterogeneity among patients with identical apoAl variants implies that other genetic and environmental factors influence clinical manifestations and support the need for $A P O A /$ gene sequencing in patients with apparent localized amyloidosis, particularly involving the larynx or skin.

\section{Acknowledgments}

We acknowledge all of the physicians and surgeons who were involved in the clinical care of the patients reported in this study.

\section{References}

1. Ostertag B: Demonstration einer eigenartigen familiaren paraamyloidose. Zentralbl Aug Pathol 1932, 56:253-254

2. Jones LA, Harding JA, Cohen AS, Skinner M: New USA family has apolipoprotein Al (Arg26) variant. Edited by Natvig JB, Førre $\varnothing$, Husby G, Husebekk A, Skogen B, Sletten K, Westermark P. Dordrecht, Kluwer Academic Publishers, 1991, pp. 385-388

3. Soutar AK, Hawkins PN, Vigushin DM, Tennent GA, Booth SE, Hutton T, Nguyen O, Totty NF, Feest TG, Hsuan JJ, Pepys MB: Apolipoprotein Al mutation Arg-60 causes autosomal dominant amyloidosis. Proc Natl Acad Sci U S A 1992, 89:7389-7393

4. Booth DR, Tan SY, Booth SE, Hsuan JJ, Totty NF, Nguyen O, Hutton T, Vigushin DM, Tennent GA, Hutchinson WL, Thomson N, Soutar AK, Hawkins PN, Pepys MB: A new apolipoprotein Al variant. Trp50Arg, causes hereditary amyloidosis. Q J Med 1995, 88:695-702

5. Booth DR, Tan SY, Booth SE, Tennent GA, Hutchinson WL, Hsuan JJ, Totty NF, Nguyen O, Soutar AK, Hawkins PN, Bruguera M, Caballería J, Solé M, Campistol JM, Pepys MB: Hereditary hepatic and systemic amyloidosis caused by a new deletion/insertion mutation in the apolipoprotein Al gene. J Clin Invest 1996, 97:2714-2721

6. Persey MR, Booth DR, Booth SE, van Zyl-Smit R, Adams BK, Fattaar AB, Tennent GA, Hawkins PN, Pepys MB: Hereditary nephropathic systemic amyloidosis caused by a novel variant apolipoprotein A-I. Kidney Int 1998, 53:276-281

7. Hamidi AsI K, Liepnieks JJ, Nakamura M, Parker F, Benson MD: A novel apolipoprotein A-1 variant. Arg173Pro, associated with cardiac and cutaneous amyloidosis. Biochem Biophys Res Commun 1999, 257:584588

8. Hamidi Asl L, Liepnieks JJ, Hamidi AsI K, Uemichi T, Moulin G, Desjoyaux E, Loire R, Delpech M, Grateau G, Benson MD: Hereditary amyloid cardiomyopathy caused by a variant apolipoprotein A1. Am J Pathol 1999, 154:221-227

9. Obici L, Bellotti V, Mangione P, Stoppini M, Arbustini E, Verga L, Zorzoli I, Anesi E, Zanotti G, Campana C, Viganò M, Merlini G: The new apolipoprotein A-I variant Leu ${ }^{174} \rightarrow$ Ser causes hereditary cardiac amyloidosis, and the amyloid fibrils are constituted by the 93residue N-terminal polypeptide. Am J Pathol 1999, 155:695-702

10. de Sousa MM, Vital C, Ostler D, Fernandes R, Pouget-Abadie J, Carles D, Saraiva MJ: Apolipoprotein Al and transthyretin as components of amyloid fibrils in a kindred with apoAI Leu178His amyloidosis. Am J Pathol 2000, 156:1911-1917

11. Murphy CL, Wang S, Weaver K, Gertz MA, Weiss DT, Solomon A: Renal apolipoprotein A-I amyloidosis associated with a novel mutant Leu64Pro. Am J Kidney Dis 2004, 44:1103-1109

12. Obici L, Palladini G, Giorgetti S, Bellotti V, Gregorini G, Arbustini E, Verga L, Marciano S, Donadei S, Perfetti V, Calabresi L, Bergonzi C,
Scolari F, Merlini G: Liver biopsy discloses a new apolipoprotein A-I hereditary amyloidosis in several unrelated Italian families. Gastroenterology 2004, 126:1416-1422

13. Benson MD, Liepnieks JJ, Yazaki M, Yamashita T, Hamidi Asl K, Guenther B, Kluve-Beckerman B: A new human hereditary amyloidosis: the result of a stop-codon mutation in the apolipoprotein All gene. Genomics 2001, 72:272-277

14. Benson MD, Liepnieks J, Uemichi T, Wheeler G, Correa R: Hereditary renal amyloidosis associated with a mutant fibrinogen $\alpha$-chain. Nat Genet 1993, 3:252-255

15. Uemichi T, Liepnieks JJ, Benson MD: Hereditary renal amyloidosis with a novel variant fibrinogen. J Clin Invest 1994, 93:731-736

16. Uemichi T, Liepnieks JJ, Yamada T, Gertz MA, Bang N, Benson MD: A frame shift mutation in the fibrinogen $\mathrm{A} \alpha$-chain gene in a kindred with renal amyloidosis. Blood 1996, 87:4197-4203

17. Hamidi AsI L, Liepnieks JJ, Uemichi T, Rebibou JM, Justrabo E, Droz D, Mousson C, Chalopin JM, Benson MD, Delpech M, Grateau G: Renal amyloidosis with a frame shift mutation in fibrinogen a $\alpha$-chain gene producing a novel amyloid protein. Blood 1997, 90:4799-4805

18. Pepys MB, Hawkins PN, Booth DR, Vigushin DM, Tennent GA, Soutar AK, Totty N, Nguyen O, Blake CCF, Terry CJ, Feest TG, Zalin AM, Hsuan JJ: Human lysozyme gene mutations cause hereditary systemic amyloidosis. Nature 1993, 362:553-557

19. Nichols WC, Gregg RE, Brewer HBJ, Benson MD: A mutation in apolipoprotein A-l in the lowa type of familial amyloidotic polyneuropathy. Genomics 1990, 8:318-323

20. Hazenberg AJ, Dikkers FG, Hawkins PN, Bijzet J, Rowczenio D, Gilbertson J, Posthumus MD, Leijsma MK, Hazenberg BP: Laryngeal presentation of systemic apolipoprotein A-I-derived amyloidosis. Laryngoscope 2009, 119:608-615

21. Kyle RA, Gertz MA: Primary systemic amyloidosis: clinical and laboratory features in 474 cases. Semin Hematol 1995, 32:45-59

22. Kyle RA, Gertz MA, Greipp PR, Witzig TE, Lust JA, Lacy MQ: A trial of three regimens for primary amyloidosis: colchicine alone, melphalan and prednisone, and melphalan, prednisone, and colchicine. N Engl J Med 1997, 336:1202-1207

23. Puchtler $\mathrm{H}$, Sweat $F$, Levine $M$ : On the binding of Congo red by amyloid. J Histochem Cytochem 1962, 10:355-364

24. Tennent GA, Cafferty KD, Pepys MB, Hawkins PN: Congo red overlay immunohistochemistry aids classification of amyloid deposits. Edited by Kyle RA, Gertz MA. Pearl River, New York, Parthenon Publishing, 1999, pp. 160-162

25. Talmud P, Tybjaerg-Hansen A, Bhatnagar D, Mbewu A, Miller JP, Durrington $P$, Humphries S: Rapid screening for specific mutations in patients with a clinical diagnosis of familial hypercholesterolaemia. Atherosclerosis 1991, 89:137-141

26. Hawkins PN, Lavender JP, Pepys MB: Evaluation of systemic amyloidosis by scintigraphy with 123l-labeled serum amyloid P component. N Engl J Med 1990, 323:508-513

27. Bradwell AR, Carr-Smith HD, Mead GP, Tang LX, Showell PJ, Drayson MT, Drew R: Highly sensitive, automated immunoassay for immunoglobulin free light chains in serum and urine. Clin Chem 2001, 47:673-680

28. Shoulders CC, Kornblihtt AR, Munro BS, Baralle FE: Gene structure of human apolipoprotein A1. Nucleic Acids Res 1983, 11:2827-2837

29. Kyle RA, Therneau TM, Rajkumar SV, Larson DR, Plevak MF, Offord JR, Dispenzieri A, Katzmann JA, Melton LJ III: Prevalence of monoclonal gammopathy of undetermined significance. N Engl J Med 2006, 354:1362-1369

30. Lachmann HJ, Booth DR, Booth SE, Bybee A, Gilbertson JA, Gillmore JD, Pepys MB, Hawkins PN: Misdiagnosis of hereditary amyloidosis as AL (primary) amyloidosis. N Engl J Med 2002, 346:1786-1791

31. Novak L, Cook WJ, Herrera GA, Sanders PW: AL-amyloidosis is underdiagnosed in renal biopsies. Nephrol Dial Transplant 2004, 19:3050-3053

32. Solomon A, Murphy CL, Westermark P: Unreliability of immunohistochemistry for typing amyloid deposits. Arch Pathol Lab Med 2008, 132:14-15

33. Vrana JA, Gamez JD, Madden BJ, Theis JD, Bergen HR III, Dogan A: Classification of amyloidosis by laser microdissection and mass spectrometry-based proteomic analysis in clinical biopsy specimens. Blood 2009, 114:4957-4959

34. Gillmore JD, Lachmann HJ, Rowczenio D, Gilbertson JA, Zeng $\mathrm{CH}$, Liu ZH, Li LS, Wechalekar A, Hawkins PN: Diagnosis, pathogenesis, treatment, and prognosis of hereditary fibrinogen A alpha-chain amyloidosis. J Am Soc Nephrol 2009, 20:444-451 
35. Brewer HB, Jr., Fairwell T, LaRue A, Ronan R, Houser A, Bronzert TJ: The amino acid sequence of human APOA-I, an apolipoprotein isolated from high density lipoproteins. Biochem Biophys Res Commun 1978, 80:623-630

36. Nichols WC, Dwulet FE, Liepnieks J, Benson MD: Variant apolipoprotein $\mathrm{Al}$ as a major constituent of a human hereditary amyloid. Biochem Biophys Res Commun 1988, 156:762-768

37. Vigushin DM, Gough J, Allan D, Alguacil A, Penner B, Pettigrew NM, Quinonez G, Bernstein K, Booth SE, Booth DR, Soutar AK, Hawkins PN, Pepys MB: Familial nephropathic systemic amyloidosis caused by apolipoprotein Al variant Arg26. Q J Med 1994, 87:149-154

38. Caballeria J, Bruguera M, Sole M, Campistol JM, Rodes J: Hepatic familial amyloidosis caused by a new mutation in the apolipoprotein Al gene: clinical and pathological features. Am J Gastroenterol 2001, 96:1872-1876

39. Persey MR, Booth DR, Booth SE, van Zyl-Smit R, Hawkins PN, Pepys MB: A new deletion mutation of the apolipoprotein Al gene causing hereditary amyloidosis. Clin Sci 1996, 90(Suppl 34):33P

40. Eriksson M, Schonland S, Yumlu S, Hegenbart U, von Hutten H, Gioeva Z, Lohse P, Buttner J, Schmidt H, Rocken C: Hereditary apolipoprotein Al-associated amyloidosis in surgical pathology specimens: identification of three novel mutations in the APOA1 gene. J Mol Diagn 2009, 11:257-262

41. Coriu D, Dispenzieri A, Stevens FJ, Murphy CL, Wang S, Weiss DT, Solomon A: Hepatic amyloidosis resulting from deposition of the apolipoprotein A-I variant Leu75Pro. Amyloid 2003, 10:215-223

42. Gregorini G, Izzi C, Obici L, Tardanico R, Rocken C, Viola BF, Capistrano M, Donadei S, Biasi L, Scalvini T, Merlini G, Scolari F: Renal apolipoprotein A-I amyloidosis: a rare and usually ignored cause of hereditary tubulointerstitial nephritis. J Am Soc Nephrol 2005, 16 3680-3686

43. Amarzguioui M, Mucchiano G, Häggqvist B, Westermark P, Kavlie A, Sletten K, Prydz H: Extensive intimal apolipoprotein A1-derived amyloid deposits in a patient with an apolipoprotein A1 mutation Biochem Biophys Res Commun 1998, 242:534-539

44. Van Allen M, Frohlich J, Davis J: Inherited predisposition to generalized amyloidosis. Neurology 1969, 19:10-25

45. Joy T, Wang J, Hahn A, Hegele RA: APOA1 related amyloidosis: a case report and literature review. Clin Biochem 2003, 36:641-645 